\title{
Significance of the parkin and PINKI gene in Jordanian families with incidences of young-onset and juvenile parkinsonism

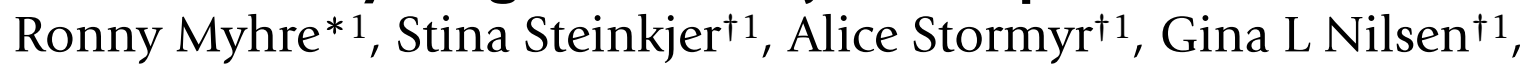 Hiba Abu Zayyad ${ }^{2}$, Khalid Horany ${ }^{3}$, Mohamad K Nusier ${ }^{2}$ and Helge Klungland ${ }^{1}$
}

Address: ${ }^{1}$ Department of Laboratory Medicine, Children's and Women's Health, Faculty of Medicine, Norwegian University of Science and Technology, N-7006 Trondheim, Norway, ${ }^{2}$ Department of Biochemistry and Molecular Biology, Faculty of Medicine, Jordan University of Science and Technology, Irbid 22110, Jordan and ${ }^{3}$ Department of Neurology, King Hussein Medical Centre, Royal Medical Services, Amman 11821, Jordan

Email: Ronny Myhre* - ronny.myhre@ntnu.no; Stina Steinkjer - stina.steinkjer@gmail.com; Alice Stormyr - alsto@ hotmail.com; Gina L Nilsen - gina.l.n@gmail.com; Hiba Abu Zayyad - hiba_zayad@yahoo.com; Khalid Horany - khalidhorany@hotmail.com; Mohamad K Nusier - mick@just.edu.jo; Helge Klungland - helge.klungland@ntnu.no

* Corresponding author †Equal contributors

Published: 16 December 2008

BMC Neurology 2008, 8:47 doi:10.1 |86/|47|-2377-8-47
Received: 3 September 2008

Accepted: 16 December 2008

This article is available from: http://www.biomedcentral.com/147/-2377/8/47

(c) 2008 Myhre et al; licensee BioMed Central Ltd.

This is an Open Access article distributed under the terms of the Creative Commons Attribution License (http://creativecommons.org/licenses/by/2.0), which permits unrestricted use, distribution, and reproduction in any medium, provided the original work is properly cited.

\begin{abstract}
Background: Parkinson's disease is a progressive neurodegenerative disorder, where most cases are sporadic with a late onset. In rare incidences familial forms of early-onset parkinsonism occur, and when recessively inherited, cases are often explained by mutations in either the parkin (PARK2) or PINKI (PARK6) gene or on exceptional occasions the DJ-I (PARK7) or ATPI3A2 (PARK9) gene. Recessively inherited deletions/duplications and point mutations in the parkin gene are the most common cause of early-onset parkinsonism known so far, but in an increasing number of studies, genetic variations in the serine/threonine kinase domain of the PINKI gene are found to explain early-onset parkinsonism.

Methods: In this study all families were from a population with a high incidence of consanguinity. We investigated II consanguineous families comprising 17 affected with recessively inherited young-onset parkinsonism for mutations both in the parkin and PINKI gene. Exons and flanking regions were sequenced, and segregation patterns of genetic variation were assessed in members of the respective families. An exon dosage analysis was performed for all exons in both genes.

Results: In the parkin gene, a three generation family was identified with an exon 4 deletion segregating with disease. Both affected were homozygous for the deletion that segregated on a haplotype that spanned the gene in a haplotype segregation analysis that was performed using additional markers. Exon dosage analysis confirmed the recessive pattern of inheritance with heterozygous deletions segregating in healthy family members. In the PINKI gene we identified two novel putative pathogenic substitutions, P4I6R and S4I9P, located in a conserved motif of the serine/threonine kinase domain. Both substitutions segregated with disease in agreement with a recessive pattern of inheritance within respective families and both were present as homozygous in two affected each. We also discuss common polymorphisms in the two genes found to be co-segregating within families.
\end{abstract}

Conclusion: Our results further extend on the involvement of PINKI mutations in recessive early-onset parkinsonism with clinical features similar to carriers of parkin mutations. 


\section{Background}

Parkinson's disease (PD) is a neurodegenerative disorder recognised by a combination of the different motor symptoms rigidity, tremor, postural instability and bradykinesia $[1,2]$. Although the onset of PD is, in most cases, considered to be sporadic, individuals with a first-degree relative with PD are at greater risk of developing disease. According to familial aggregation studies the risk of developing PD for first-degree relatives is 2-14 times higher than for those with no family history of PD with relatives of late-onset at the lower and early-onset at the higher end of the range [3-5].

Only a few genes are known to be recessively inherited in early-onset parkinsonism. These genes are parkin [6], PINK1 [7], DJ-1 [8] and ATP13A2 [9]. The most common form of early-onset parkinsonism known so far is autosomal recessive juvenile parkinsonism (AR-JP), caused by loss-of-function mutations in the parkin gene [10]. AR-JP was first discovered and described in Japanese families [11-14] and subsequently linked to 6q25.2-27 [PARK2; OMIM 600116] [15]. The parkin gene was characterized by Kitada et al. [6], and has four motifs; an ubiquitin-like domain in the amino-terminal and a RING1-in-betweenRINGS (IBR)-RING2 structure in the carboxyl terminal [16]. This characteristic structure links the Parkin protein to the ubiquitin-proteasome system [6].

Different classes of mutations have been described in the parkin gene [6] and recent studies have identified several deletions, duplications and point mutations in individuals with this form of parkinsonism [17-20] estimated to be responsible for $50 \%$ of autosomal recessive early-onset and $18-20 \%$ of sporadic early-onset cases of parkinsonism $[10,21]$. A possible role for autosomal dominant or compound heterozygous effects of mutations has also been suggested [22].

PINK1 was identified as the gene associated to the PARK6 candidate region of PD, mapped to 1p36 [PARK6; OMIM $605909]$ by Valente and colleagues $[7,23,24]$. The gene encodes a PTEN-induced putative kinase1 (PINK1) with a serine/threonine kinase motif and a mitochondrial targeting sequence [7]. Recently, several mutations in PINK1 have been recognised as disease causative in a growing number of families with early-onset autosomal recessive parkinsonism [25-30], and in sporadic early-onset parkinsonism [31]. The effect of heterozygous mutations and a possible existence of gain of function mutations with dominant transmission has been discussed [32].

Most PD associated mutations have been identified in the serine/threonine kinase domain potentially affecting the kinase activity or possibly the substrate binding ability $[7,25-27,29,32-38]$. The serine/threonine kinase activity of this segment was confirmed by Sim and colleagues [33] using the kinase domain and C-terminal in truncation experiments. Cell culture studies identified a mitochondrial localisation and function of PINK1 [39].

Clinically, patients with parkin mutations are observed as levodopa-responsive parkinsonism [41,42] with a relatively long duration and slow progression $[40,41]$. As a generalization, the common symptoms of PINK1 mutation carriers are clinically described as comparative to symptoms of sporadic PD except for earlier onset and slower disease progression $[28,30,34]$, however, sometimes without dystonia and sleep benefit, which is common for carriers of parkin mutations $[7,10]$.

We examined families from Jordan with a high incidence of consanguineous marriages, a recessive pattern of inheritance, and at least one patient with parkinsonism in each family to investigate the significance of parkin and PINK1 mutations in the region. In light of the ongoing discussion regarding the impact of heterozygous mutations in both parkin and PINK1, and to discuss a possible effect of mutational load, we present nearly full distribution of substitutions observed.

\section{Methods \\ Patients}

This study included 11 consanguineous families with 1-2 affected with juvenile or young-onset parkinsonism with a total of 59 family members with 17 affected. Five families had only one affected member strictly classified as having young-onset sporadic parkinsonism. The age at onset was on average $26.8 \pm 5.8$ years [range 19-36] covering cases defined as either young $(\geq 21$ and $<40)$ or juvenile $(<21)$ onset $[43,44]$.

The parents were unaffected with the absence of disease in several generations suggesting an autosomal recessive mode of inheritance. Clinical manifestations included marked response to levodopa (60\%), sleep benefit (95\%), observed L-dopa induced dyskinesia (90\%), dystonic posture $(90 \%)$, and a slow disease progression $(90 \%)$. Families $\mathrm{A}, \mathrm{B}, \mathrm{C}, \mathrm{D}, \mathrm{E}$ and $\mathrm{K}$ were inhabitants of the same geographic region in north-Jordan while families $\mathrm{F}, \mathrm{G}, \mathrm{H}$, I and J were inhabitants at different locations of mid-Jordan.

\section{Genetic studies}

DNA was collected from all available family members. Blood samples were collected on EDTA tubes after gathering informed consent from each participant in compliance with the Helsinki Declaration and the project was approved by the research ethics committee for research on human, headed by the dean of Medical School Jordan. DNA was extracted using Wizard ${ }^{\circledR}$ DNA Extraction kit 
(Promega). All DNA samples were amplified using GenomiPhi DNA Amplification Kit (Amersham Bioscience Corp) due to limited amounts of DNA. Verification of family relations were performed with the AmpFISTR $^{\circledast}$ profiler $^{\circledast}$ kit (Applied Biosystems, Foster City, CA, USA) according to the manufacturer's protocol.

Coding regions of parkin (exons 1-12, primers available on request) and PINK1 (exons 1-8) were sequenced using primers from Hatano et al [25] and additional primers for exon 5 from Schlitter et al [45]. DNA amplification was performed with $10 \mu \mathrm{M}$ of each primer, GeneAmp 10× buffer II (Applied Biosystems), $25 \mu \mathrm{M} \mathrm{MgCl}_{2}, 10 \mu \mathrm{M}$ $\mathrm{dNTP}$ and Taq Polymerase (250 Units, $5 \mathrm{U} / \mu \mathrm{l}$ ). The PCR was run for 45 cycles at $96^{\circ} \mathrm{C}$ for $30 \mathrm{sec}$, annealing temperature for $30 \mathrm{sec}$ and $72^{\circ} \mathrm{C}$ for $30 \mathrm{sec}$. Sequencing reactions were performed with BigDye Terminator v3.1 Cycle Sequencing Kit (Applied Biosystems) according to manufacturers manual using 3,2 pmol primer and 30-90 ng DNA template, run for 25 cycles at $96^{\circ} \mathrm{C}$ for $10 \mathrm{sec}$, annealing temperature for $5 \mathrm{sec}$ and $60^{\circ} \mathrm{C}$ for $4 \mathrm{~min}$. Special PCR procedure was used for the GC rich exon 1 (method available on request).

To perform haplotype segregation analysis we genotyped four microsatellite markers (D6S1599, D6S305, D6S411 and D6S1550) frequently analysed in parkin. The markers were amplified using $10 \mu \mathrm{M}$ of each primer, GeneAmp $10 \times$ buffer II (Applied Biosystems), $25 \mu \mathrm{M} \mathrm{MgCl}_{2}, 10 \mathrm{mM}$ $\mathrm{dNTP}$ and Taq polymerase Gold ( 250 units, $5 \mathrm{U} / \mu \mathrm{l})$. The PCR was run for 40 cycles at $96^{\circ} \mathrm{C}$ for $30 \mathrm{sec}$, annealing temperature for $30 \mathrm{sec}$ and $72^{\circ} \mathrm{C}$ for $30 \mathrm{sec}$.

To map the deletion size, PCR reactions were performed of $200 \mathrm{bp}$ fragments at increasingly closer intervals to the breakpoints according to the following conditions; $10 \mu \mathrm{M}$ of each primer, GeneAmp 10× buffer II (Applied Biosystems), $25 \mu \mathrm{M} \mathrm{MgCl}_{2}, 10 \mathrm{mM} \mathrm{dNTP}$ and Taq polymerase Gold ( 250 units, $5 \mathrm{U} / \mu \mathrm{l}$ ). The PCR was run for 45 cycles at $96^{\circ} \mathrm{C}$ for $30 \mathrm{sec}$, annealing temperature for $30 \mathrm{sec}$ and $72^{\circ} \mathrm{C}$ for $30 \mathrm{sec}$.

Multiple sequence alignment was performed using ClustalW software available at the European Bioinformatics Institute http://www.ebi.ac.uk/clustalw/ to evaluate conservation of amino acids in the parkin and PINK1 gene across species. Tolerance of the substitutions observed was predicted using SIFT v.2 http://blocks.fhcrc.org/sift/ SIFT.html. Gene exon dosage analysis was performed using the SALSA MLPA P051/P052B kit (MRC-Holland) according to the manufacturer's protocol. Fragments were analysed using GeneMapper v3.7 (Applied Biosystems) and interpretation of results was performed with the Coffalyser v4 software package (MRC-Holland). When not specified in method, fragments and sequences were ana- lysed on an ABI 3130xl Genetic Analyzer (Applied Biosystems, Foster City, CA, USA)

\section{Results}

In Family F, a three generational pedigree we identified an exon 4 deletion in the parkin gene and substitutions in the PINK1 gene co-segregating with disease making an interesting contribution to the discussion on possible digenic effects. Additionally, two non-synonymous substitutions and one synonymous substitution was observed in the parkin gene (figure $1 \mathrm{a}, \mathrm{c}$ ). Five non-synonymous substitutions and three synonymous substitutions were identified and among these, two novel substitutions, P416R and S419P, are proposed to be pathogenic mutations. In six families there were carriers of one or more of the PINK1 non-synonymous substitutions. In four of these families, substitutions were present as homozygous or compound heterozygous in affected individuals where substitutions segregated with disease in a pattern compatible with recessive inheritance (figure 1b-f) (Overview Table 1).

\section{Non-synonymous substitutions}

In the parkin gene, Gln34Arg $(202 A>G)$ was observed in family G (patient II.3) whereas Val380Leu (1139G>C) was observed in family A (patient II.2). Both were in heterozygous state (Segregation patterns figure 1a,c). Multiple sequence alignment showed that Gln34Arg is conserved across mammals and that Val380Leu is limited conserved across mammals (Figure 2a). Both substitutions were predicted by SIFT to be tolerated with a high degree of sequence information (Seq Rep $=0.78$ ).

In the PINK1 gene four non-synonymous substitutions were in the serine/threonine kinase domain located to amino acids 156-509 [7]. Substitutions identified in this domain was in exon 5 (A340T), exon 6 (P416R) and exon 7 (S419P and E476K). An additional non-synonymous substitution was located in a large conserved domain 3 ' of the kinase domain (Figure $2 b$ ).

The A340T substitution is in a region conserved in primates but not throughout mammals, as illustrated in Rattus norwegicus as well as in Mus musculus where threonine is the conserved amino acid (Figure 2b). This substitution is found in two families (family F and J, Figure $3 \mathrm{~b}$ and figure 1f).

In this material, the substitution in the most conserved region is the P416R substitution located in an APE site within the kinase domain, a universally conserved activation segment motif and most likely essential for protein function. This mutation was found in a single family (family G) and was homozygous in both affected individuals (Figure 1c). In close proximity to this universally conserved APE motif is the S419P substitution. This is a 


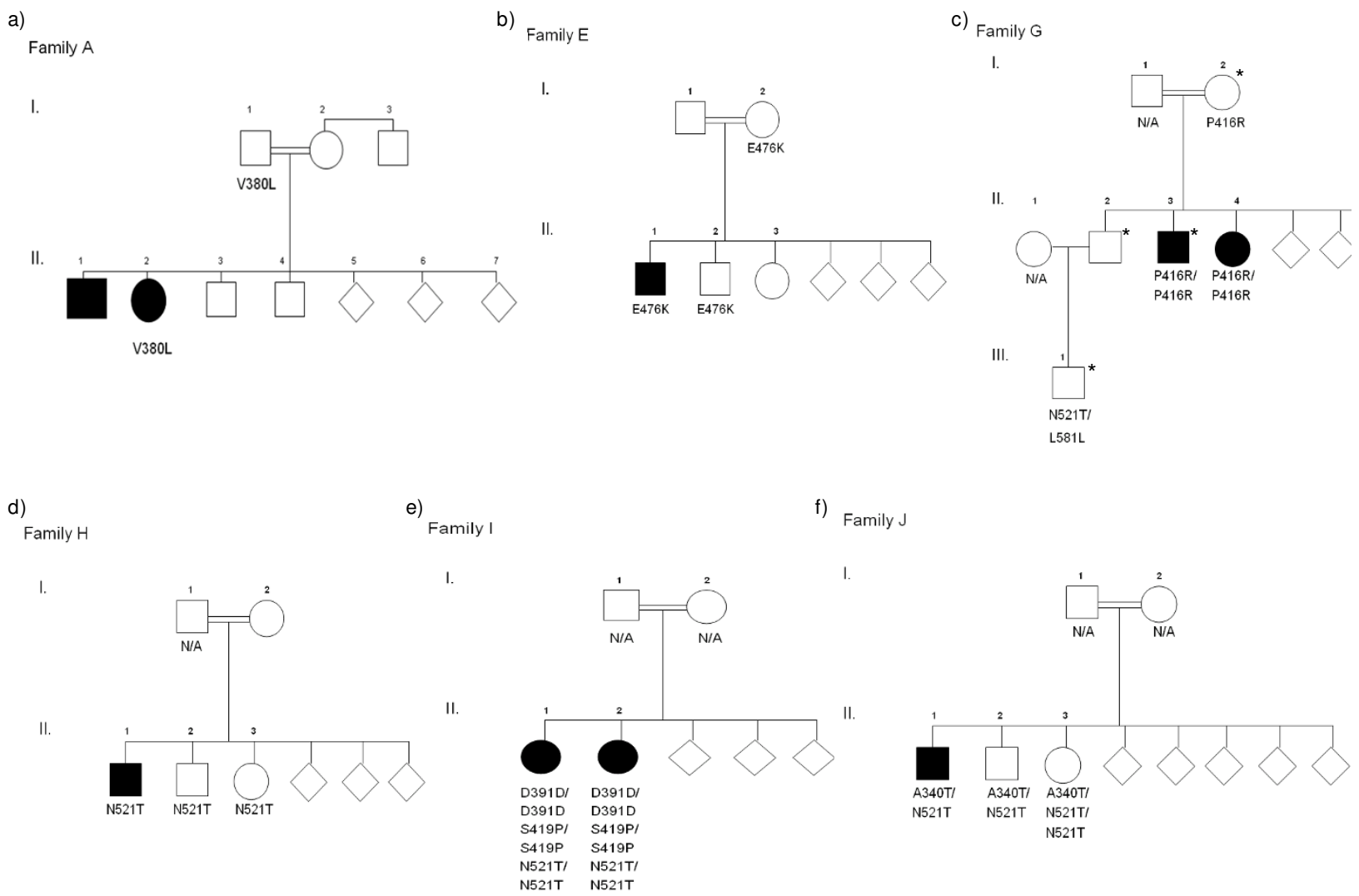

\section{Figure I}

a-f: Family pedigrees with segregation patterns of substitutions identified in Jordanian families with youngonset parkinsonism. c The P4I6R mutation is present as homozygous in both affected of family G. An asterisk shows parkin Q34R segregation. e In family I the S4 I9P mutation is present in homozygous state in both affected together with the putative polymorphisms D39ID and N52I. a-f Substitutions presented in the pedigrees. The A340T, E476K and N52 IT substitutions could be discussed, regarding mutational load and effect on disease development. An accumulation of substitutions are observed in some of the pedigrees. (N/A -Not available for DNA analysis).

putatively important structural change, in a region conserved across mammals. The substitution was homozygous in both affected of one family (family I) and was present together with D391D and N521T both in homozygous state (Figure 1e).

The E476K substitution represents a change in amino acid charge in a residue moderately conserved across mammals. In addition, lysine is the species specific amino acid in the Rattus norwegicus form of the PINK1 gene, indicating a less severe alteration. Together with N521T this substitutions was found to segregate with disease in one large family (family F) and as heterozygous in members of an additional family (family E, Figure 1b).

The N521T substitution is in exon 8, outside the serine/ threonine kinase region, in a conserved region comprising a large sequence at the 3 ' of the protein. The region is con- served across all mammals but has an unknown function. The N521T substitution identified in this region is the most prevalent in our material and also one of the most common substitution found in cases and family members with early onset parkinsonism, as well as in controls in other studies and is regarded as a polymorphism and not a disease causing mutation $[27,31,46]$. This variation is present as compound heterozygous in both affected of family $F$ and as compound heterozygous in the only affected of family J (Figure 1f). In family F, the N521T substitution is present with $\mathrm{E} 476 \mathrm{~K}$ and in family $\mathrm{J}$ it is present with A340T. The N521T substitution is also present as homozygous in both affected of family I. However, in family I the substitution is present with S419P, also homozygous and presumably the most prominent substitution of the two. A juvenile onset of parkinsonism was observed in family $\mathrm{H}$ with the affected only heterozygous for N521T. 
Table I: Synonymous and non-synonymous substitutions found in the parkin and PINKI gene in affected with parkinsonism.

\begin{tabular}{|c|c|c|c|c|c|}
\hline \multirow[t]{2}{*}{ Family } & \multirow[t]{2}{*}{ Affected } & \multicolumn{2}{|c|}{ Substitutions in Gene } & \multirow[t]{2}{*}{ Gender } & \multirow[t]{2}{*}{ Age at onset } \\
\hline & & Parkin & PINKI & & \\
\hline \multirow[t]{2}{*}{ Family A } & II.I & ND & ND & Male & 30 \\
\hline & 11.2 & V380L (He) & ND & Female & 28 \\
\hline Family B & II. I & ND & L63L $(\mathrm{He})$ & Female & 23 \\
\hline Family C & II. I & ND & ND & Female & 20 \\
\hline \multirow[t]{2}{*}{ Family D } & II.I & ND & ND & Female & 25 \\
\hline & 11.2 & ND & L63L $(\mathrm{He})$ & Female & 20 \\
\hline Family E & II. I & ND & $\mathrm{E} 476 \mathrm{~K}(\mathrm{He})$ & Male & 20 \\
\hline \multirow[t]{2}{*}{ Family F } & 11.2 & Exon4 $\Delta(\mathrm{H})$ & E476K, N52IT (CH) & Male & 32 \\
\hline & II.4 & Exon4 $\Delta(\mathrm{H})$ & E476K, N52IT (CH) & Male & 32 \\
\hline \multirow[t]{2}{*}{ Family G } & 11.2 & ND & P4I6R (H) & Male & 23 \\
\hline & 11.3 & VI7V, Q34R (CH) & P4I6R (H) & Female & 25 \\
\hline Family H & II. I & ND & $\mathrm{N} 521 \mathrm{~T}(\mathrm{He})$ & Male & 19 \\
\hline \multirow[t]{2}{*}{ Family I } & II.I & ND & D39ID, S4I9P, N52IT (all H) & Female & 36 \\
\hline & 11.2 & ND & D39ID, S4I9P, N52IT (all H) & Female & 35 \\
\hline Family J & II.I & ND & $\mathrm{A} 340 \mathrm{~S}, \mathrm{~N} 52 \mathrm{IT}(\mathrm{CH})$ & Male & 36 \\
\hline \multirow[t]{2}{*}{ Family K } & II.I & ND & L63L & Female & 25 \\
\hline & 11.2 & ND & L63L & Male & 27 \\
\hline
\end{tabular}

Putative pathogenic mutations are in bold. $\mathrm{CH}$ - compound heterozygous; $\mathrm{H}$ - Homozygous; $\mathrm{He}-$ Heterozygous; $\Delta-$ deletion; ND - none detected.

We did not identify any non-synonymous substitutions within family A-D and $\mathrm{K}$ which were all from the same region in Jordan (north-Jordan). Family E was the only family from that region making an exception with an E476K non-synonymous substitution in the PINK1 gene. The family was identified through a single affected, strictly classifying this as sporadic young-onset parkinsonism.

\section{Synonymous substitutions}

Additionally to the substitutions described above, we observed a synonymous substitution, Val17Val (152C>T), in parkin in family G. In PINK1 three synonymous substitutions, L63L in exon 1, D391D in exon 6 and L581L in exon 8 were identified. The L63L substitution was present in four affected; family B patient II.1, family D patient II. 2 and family K patient II.1 and patient II.2 (data not shown in figure 1) and has been identified as a polymorphism in a series of studies [45]. The D391D synonymous substitution was present in a homozygous state in family I, in both affected. However, these affected are homozygous for two additional non-synonymous substitutions (figure 1e). The L581L substitution was identified in an unaffected member of family G (member III.1). Predictions using SIFT v.2 strengthened the assumption of the A340S, E476K and N521T substitutions to be tolerable polymorphisms. P416R was predicted not tolerable while S419P was predicted marginally tolerable $(p=0.11$, threshold $\mathrm{p}=0.05$ ).

Among other noteworthy observations was a tendency of substitutions to accumulate in families. Substitutions are introduced into the pedigree of both family $F$ and $G$ and

\section{Parkin}

Homo sapiens

Pan troglodytes

Rattus norwegicus

Mus musculus

$\begin{array}{cl}\text { Q34R } & \text { V380L } \\ \text { SIFQLKE VWAKR GVPADQLRVIFA } & \text { KVTCE GGNGL GCGVSTAHTP ---- } \\ \text { SIFQLKE VWAKR GWPADQLRVIFA } & \text { KVTCE GGNGL GCGVSTAHTP ---- } \\ \text { SIFQLKE WHKR GVPADQLRVIFA } & \text { KVTCE GGNGL GCGVT FCRDCRMR- } \\ \text { SILQLKE VWAKR GWPADQLRVIFA } & \text { KVTCE GGNGL GCGFV FCRDCKEAY }\end{array}$

A340T P416R 5419P E476K N521T

PRLAAMML L CLMAPEVSTARP PALPESVPP EHILALKNLKLDKMVGWLLQQSAATLLANRLTE PRLAAMML L CLMAPEVSTARP PALPESVPP EHILALKNLKLDKMVGULLQQSAATLLASRLTE SRLATMITL SLMAPEVSTAHS PEMPKSVPP EHLLALKNLKLDKMIAULLQQSAATLLADRLRE SRLATMMT SLMAPEVSTAHS PEMPESVPP EHLLALKNLKLDKMIAULLQQSAATLLADRLRE
PDik1

Homo sapiens

Pan troglodytes

Rattus norwegicus

Mus musculus

\section{Figure 2}

Multiple sequence alignment of substitutions in the parkin and PINKI gene across species using ClustalW version I.83. Substitutions are highlighted where conserved and flanked by neighbouring amino acids. 

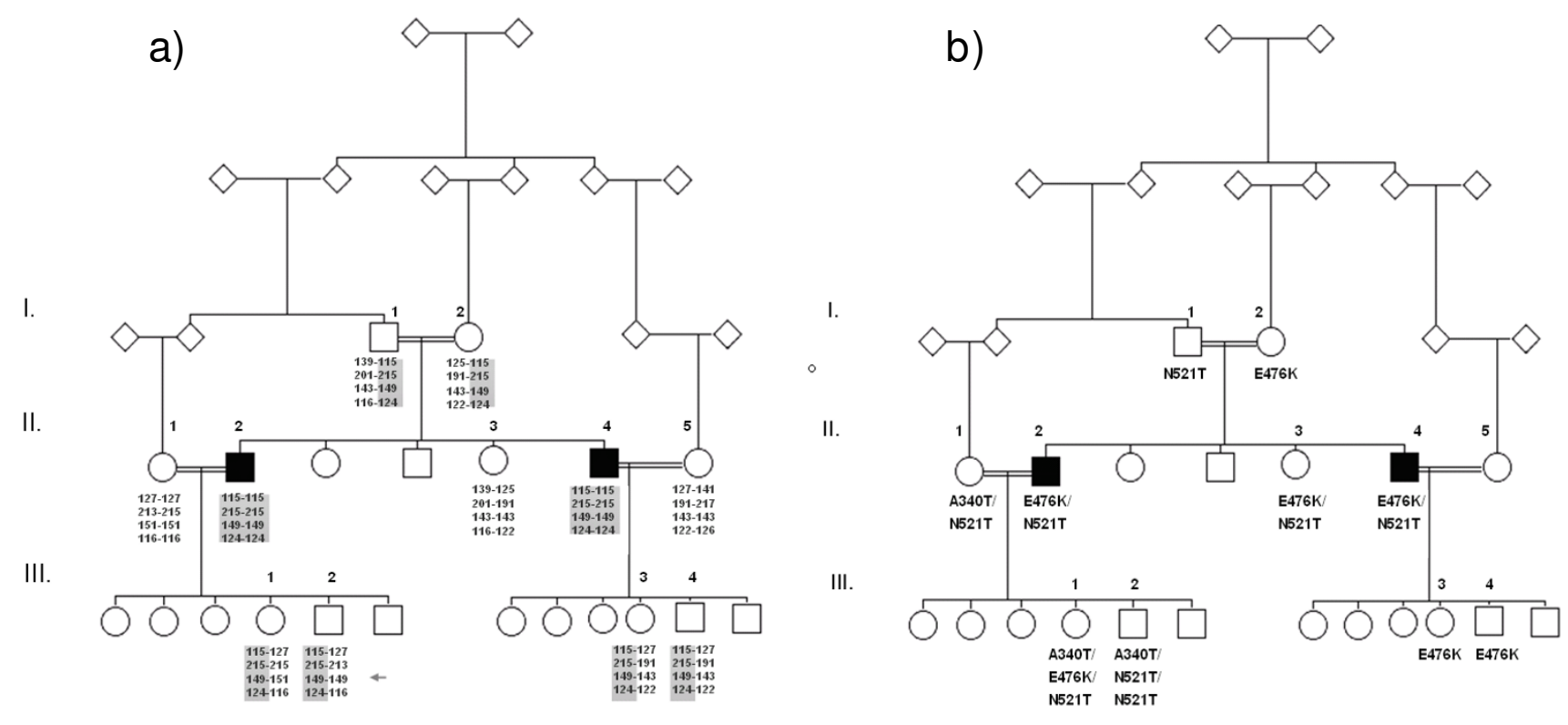

Figure 3

a-b: Segregation pattern of genetic variation in family F. Parents of the two affected are |st cousins. One affected (II.2) is married to his Ist cousin, whereas the other affected (II.4), is married to his $3^{\text {rd }}$ cousin. a Segregation of haplotype and parkin exon 4 deletion. Both patients were homozygous for a haplotype of four parkin microsatellite markers, and an exon 4 deletion was found to segregate with disease in the family. Gray area denotes haplotype containing exon 4 deletion. b Segregation of substitutions observed in PINKI. Both affected are compound heterozygous for the substitutions generally evaluated as common polymorphisms. One of the children, III.2, had a microsatellite mutation or a rarer double recombination (arrow). The fragment lengths of microsatellite markers D6SI599, D6S305, D6S4I I and D6SI 550 are listed beneath each individual.

seem to be highly accumulated in family I. Accumulation of substitutions is a trait expected to appear in highly consanguineous families when clinical symptoms are known or anticipated (selection bias).

\section{Gene dosage}

Gene dosage analysis was performed with SALSA MLPA probe set P051 and P052B in affected and/or informative family members of all families. In members of family $F$, an exon 4 deletion was identified to segregate in a recessively inheritance pattern and homozygous deletions were identified in both affected. Family $\mathrm{H}$ had inconsistent control samples and no result was achieved. The extent of the deletion was investigated and a composite exon 4 deletion was observed consisting of one large $\sim 25.600$ bp and one small $\sim 400$ bp deletion (figure 4 ).

\section{Haplotype segregation}

DNA samples were genotyped using four microsatellite markers located within the parkin gene with the intent to study the inheritance of markers and assess whether if an inherited haplotype could explain the development of PD in some of these families. Homozygous haplotypes were observed only in the two affected in family F. Figure 3a shows the pedigree of family F, where the two patients II.2 and II.4 are homozygous for all markers analysed within the parkin gene. We looked at correct phasing to identify any recombination events. Recombination was observed in a healthy individual in family B, offspring II.5 (family tree not shown) and family F, offspring III.2. We also observed recombination events in both the affected offspring (II.1 and II.2) in family K (family tree not shown). The haplotype segregation analysis was used to establish family relations together with results from the AmpFISTR ${ }^{\circledR}$ profiler $^{\circledast}$ kit. Based on these results, two families were excluded prior to this study. A female cousin in family $G$ was also excluded prior to this study along with two members of family F.

\section{Discussion}

The families included in our study are from regions with a high prevalence of consanguinity, favouring an increased frequency of genetic homozygosity and diseases with recessive inheritance. From the literature, it is well known that genetic variation within the parkin gene cause autosomal recessive juvenile parkinsonism (AR-JP) $[6,10,17-20,22,40]$ and is the most common cause of familial parkinsonism known to date [10], while mutations in the PINK1 gene are recognized as an increasingly important genetic cause of early-onset parkinsonism. A 


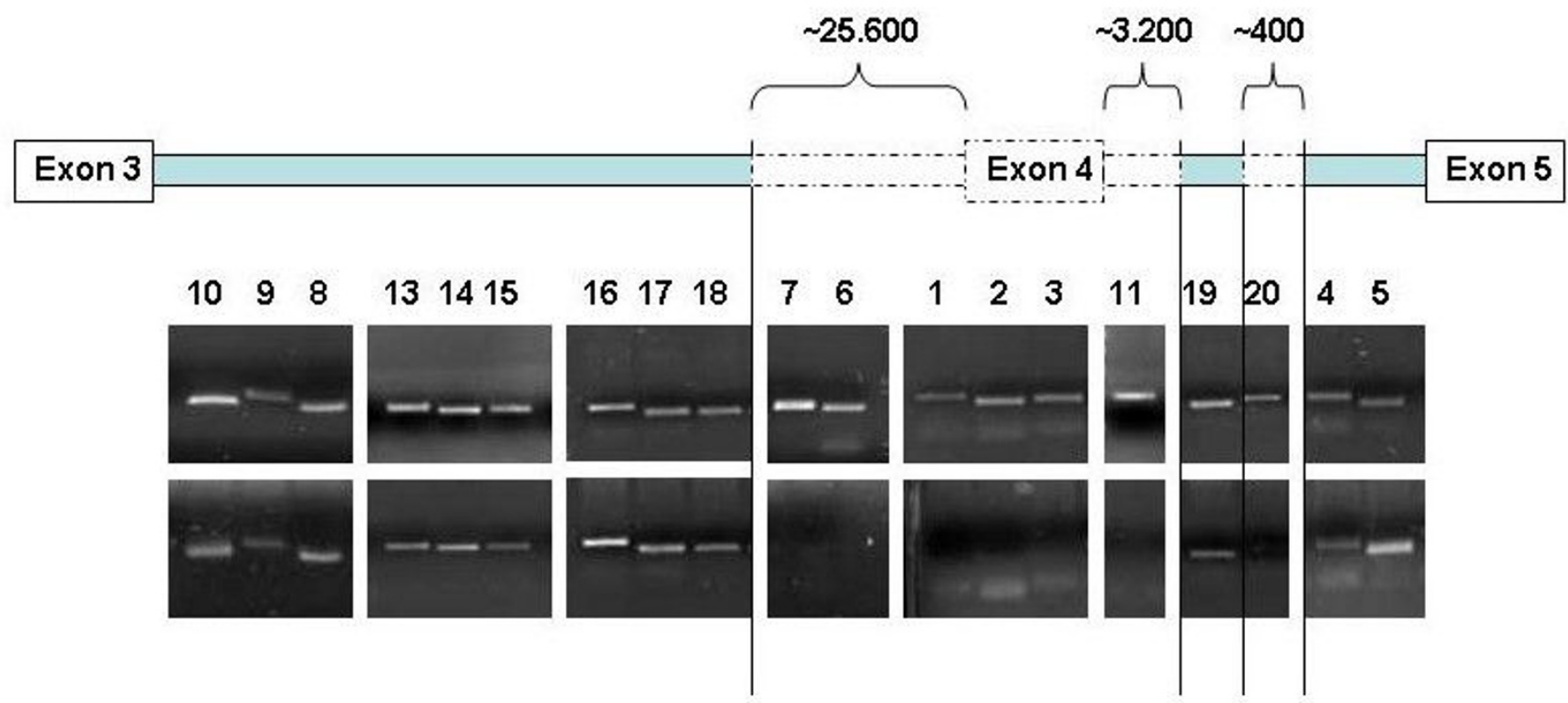

\section{Figure 4}

Mapping of the parkin exon 4 deletion in family F. A composite deletion was identified consisting of one large $\sim 25.600$ bp and one small $\sim 400$ bp deletion and presence of fragment 19 confirmed by two additional flanking primers. Gel pictures represent control (top row) and patient II. 4 of family $\mathrm{F}$ (bottom row).

possible effect of heterozygous mutations in both parkin and PINK1 have been proposed and a digenic effect have been observed [47]. To this end we identified an exon 4 deletion in parkin that was homozygous in both affected (figure 3a) and additional substitutions in PINK1, which co-segregated with disease (figure $3 \mathrm{~b}$ ). Some substitutions acknowledged to be common in populations are here discussed according to possible role in disease development.

In our material we identified four non-synonymous substitutions in the kinase domain of PINK1, of which two are novel and proposed to be putative pathogenic mutations. The protein kinase domain in PINK1 that is located to amino acids 156-509, has a high degree of homology to similar kinases in the $\mathrm{Ca}^{2}+/$ calmodulin family [7]. Functional studies indicate that mutations in the kinase domain are expected to effect kinase activity as well as substrate binding capability [33].

Affected individuals in these families were either homozygous or compound heterozygous and most substitutions were evaluated to be non-pathogenic polymorphisms but could be discussed in relation to impact of a single hit as well as accumulative effect of substitutions. The P416R and S419P substitutions are novel and homozygous in two affected in each of their respective families (figure 1c, e). Both are in conserved regions of the gene and predictions using SIFT software for the tolerabil- ity of substitutions indicates that especially the P416R substitution is of probable functional importance to the protein. The A340T, E476K and N521T substitutions are assumed to be non-pathogenic polymorphisms $[27,31,46]$ and the D391D synonymous substitution is assumed to have no effect [27], although the A340T substitution has been proposed to contribute to risk of development of late-onset PD [57]. Interestingly, in family F, two of these substitutions were found to co-segregate with disease. In the other families with PINK1 polymorphisms, a segregation pattern compatible with recessive inheritance could not be excluded, when taken into account the possibility of reduced penetrance in some offspring due to low age.

In family $\mathrm{F}$ we observed an E476K substitution and an N521T substitution segregating with disease. Both affected in family $\mathrm{F}$ were compound heterozygous for these putative polymorphisms in the PINK1 gene. The E476K substitution is in the protein serine/threonine kinase domain of the protein, but only to a small degree conserved across species (figure $2 \mathrm{~b}$ ). The effect of the substitution on the enzymatic activity of PINK1 is not known but the substitution is found as the conserved amino acid in several species [27] and are common in controls as well. The N521T substitution is located in a conserved region at the 3' of the protein outside the 156-509 residues proposed as the serine/threonine kinase region. This 
region is conserved across all mammals and has an unknown function. The N521T substitution identified in this region is the most prevalent in our material and thus far one of the most common substitutions found in cases as well as healthy family members with parkinsonism. In previous studies the N521T substitution has been common and recognised merely as a polymorphism $[45,58]$ and in studies of early-onset PD homozygous incidences have been confirmed in controls and cases equally $[27,31]$.

The exon 4 deletion in the parkin gene segregates with disease and explains the clinical manifestations. It is curios thou, how additional substitutions are accumulated in the PINK1 gene as revealed in this study, and for this reason the observed substitutions will be discussed.

The A340T substitution introduced into the pedigree of family $F$ was equally found in compound heterozygous state with N521T in family J. Threonine is the conserved amino acid in Rattus norwegicus and Mus musculus (figure 2) and this suggests the substitution is most likely a polymorphism. However, we cannot completely exclude a possible effect of the A340T polymorphism in combination with supplementary mutations within PINK1 or in other genes affecting parkinsonism.

Parkin is located in the third most common fragile site, FRA6E, proposed to be involved in several types of cancer, acting as a tumor suppressor gene together with other common fragile site genes such as FHIT (FRA3B ; 3p14.2) and WWOX (FRA16D;16q23) that are also associated with exon deletions [43,51]. In some cancer cells there are a high frequency of loss-of-heterozygosity (LOH) observed in D6S1599 (parkin intron 2) and D6S305 (parkin intron 6) [43] as observed in carriers in healthy family members of family $\mathrm{F}$ in our study. The mechanism of common fragile sites might indicate some of the mechanism behind the observed parkin deletions and associate the formation of deletions with a FRA6E site mechanism. The occurrence of parkin mutations could either be independently recurrent de novo mutational events or a geographical spread through founder effect. In general, exon rearrangements are found to be caused by independent de novo mutational events, while point mutations are spread mainly through founder effect $[48,49]$. The extent of the exon 4 deletion in family $F$ was further mapped and was different from one mapped in a geographically close Turkish family [50].

We found a Gln34Arg substitution previously described in India where it might be the result of a geographic founder effect $[52,53]$. In India, the substitution was observed in heterozygous state in affected with parkinsonism, but also in older unaffected family members [52].
This might be a dominant negative mutation which contributes to functional variation in the Parkin protein. A functional example may be that the protein still interacts and competes with the wild type protein for the target protein, but lacks functional properties. Therefore, in heterozygous state, this category of mutation might cause a range of phenotypes in response to genetic and environmental influence. Variation in penetrance is discussed for several parkinsonism related mutations. Dominant negative mutations may be a possible explanation of some of the observed heterozygous mutations having a variable "dominant nature". It is different from the loss-of-function mutations generally observed in the parkin gene, where a heterozygous state continues to have a normal phenotype.

Abbas and colleagues [17] previously detected a mutation in the same location of exon 2 in two British families, in which a 202-203delAG caused "loss-of-function" of the Parkin protein [17]. The Gln34Arg substitution has not yet been functionally characterized, and its function is therefore still uncertain. The localization to the ubiquitinlike domain suggests it may effect binding to proteasome subunits. The substitution was not observed in the carriers affected sister (patient II.4), who also developed the disease, stating that this substitution is not involved in disease development in both cases. More important, the affected are both carriers of homozygous P416R substitutions which probably cause the clinical symptoms (see discussion on P416R further down).

The Val380Leu mutation has, in previous studies, been found in both healthy and affected individuals. Abbas et al. [17] reported that the substitution was found in eleven European families and also $16 \%$ of the control subjects and it appear to be common across populations [52,54] and therefore not considered a main cause of disease development. It might, however, alter the Parkin protein and contribution to the pathogenesis of idiopathic PD, as noted in a study by Lucking et al. [55], which reported homozygous Val380Leu substitutions to be associated with sporadic PD. Biswas et al [56] commented on this substitution that it might be an association in some populations when ethnically stratified. In our study the substitution was heterozygous in one affected and absent in the carriers brother who also developed young-onset parkinsonism implying that the substitution was not involved in development of disease in both affected family members (figure 1a).

A recessive pattern of inheritance should, in a population with high degree of consanguinity, anticipate the observation of homozygous haplotypes identical by decent (IBD) in the parkin gene, as found in family $\mathrm{F}$ where the exon 4 deletion and all four microsatellite markers segregated 
with disease. Further haplotype assessment did not reveal any haplotype that could associate the parkin gene with the observed symptoms of young-onset or juvenile parkinsonism across families. Sequencing revealed few substitutions and we were unable to identify specific point mutations in remaining families. Quantitative analysis revealed no exon rearrangements or complete gene deletions/multiplications that could associate the parkin gene with the observed clinical symptoms. We confirmed less than expected incidences of parkin caused parkinsonism in the population. Multiple sequence alignment and estimation of the tolerability of the observed parkin substitutions indicated that they were probably tolerable (Figure $2 a)$. The reported frequency of parkin associated parkinsonism was similarly low in populations of India where the Gln34Arg substitution was previously observed $[52,53]$.

In PINK1, the novel P416R substitution was identified in family $G$, in a highly conserved motif of the activation segment in the serine/threonine kinase domain [33]. The substitution was homozygous in both affected members of the family and were the centre amino acid of an APE motif conserved in orthologous sequences and in paralogous protein kinases [33]. Located in a universally conserved functional motif the substitution is likely to affect kinase activity.

The S419P substitution was identified in family I. Two non-synonymous substitutions and one synonymous substitution, all in homozygous state, were identified in both affected members of the family (figure 2). Located in the serine/threonine kinase domain the S419P substitution was the most conserved alteration within the material.

There were no obvious differences between the ages at onset amongst putative parkin and PINK1 mutation carriers as compared to non-carriers (Table 1). However, there are similarities regarding age at onset within affected of the same family. For affected carrying P416R, the only substitution to be in a universally highly conserved motif, an earlier age at onset was seen in both affected, as compared to family I carrying three homozygous substitutions, amongst them the S419P substitution. These findings indicate a severe function of the P416R mutation, which could represent a total loss-of-function mutation. Otherwise, the observed variations in age at onset could generally be due to interactions of additional environmental or genetic factors such as accumulation of substitutions causing gradual alterations in protein structure. In light of the SIFT predictions, assessment of the tolerability of the S419P substitution is dependent on further functional analysis.
In some families an accumulation of substitutions are observed. In family F both deletion in parkin and substitutions in PINK1 co-segregate with disease, and a carrier of A340T and N521T is married in. In family G a carrier of N521T is married in to the family through a healthy family member. In family I, the accumulation of substitutions in the two affected, the only two persons available for analysis, are notable. The possibility of a $\mathrm{LOH}$ for this region was excluded using the gene and exon dosage SALSA MLPA kit. Accumulation of substitutions should suggest some selective bias based on knowledge of disease in families and therefore suggest a role of these substitutions in disease or in association to disease.

\section{Conclusion}

The role of digenic inheritance of parkin and PINK1, impact of a single mutation hit and accumulation load of gene polymorphisms are unclear. We observed a three generation family with an exon 4 deletion in the parkin gene and substitutions in the PINK1 gene co-segregating with disease indicating a potential digenic effect.

We identified two novel substitutions in the PINK1 serine/threonine kinase domain with the P416R as probable and the S419P as possible putative pathogenic mutation and the genetic cause of young-onset parkinsonism in two families.

\section{Competing interests}

The authors declare that they have no competing interests.

\section{Authors' contributions}

RM contributed to writing of manuscript, laboratory work and guidance and interpretation of results. Co-authors AS, SS and GLN performed laboratory work with interpretation of results and contributed with the manuscript. KH was the neurologist assessing the patient's diagnoses and HAZ contributed with laboratory work and interpretation of material in Jordan where MKN contributed to conception and design and was project co-ordinator. HK contributed to conception and design and was project coordinator in Norway.

\section{Acknowledgements}

We would like to thank the Jordanian families and patients who participated in the study.

\section{References}

I. Gasser T: Genetics of Parkinson's disease. J Neurol 200I, 248(10):833-840.

2. Kitada T, Asakawa S, Matsumine H, Hattori N, Shimura H, Minoshima $S$, Shimizu N, Mizuno Y: Progress in the clinical and molecular genetics of familial parkinsonism. Neurogenetics 2000, 2(4):207-218.

3. Sveinbjornsdottir $S$, Hicks AA, Jonsson T, Petursson $H$, Gugmundsson G, Frigge ML, Kong A, Gulcher JR, Stefansson K: Familial aggregation of Parkinson's disease in Iceland. N Engl J Med 2000, 343(24): 1765-1770. 
4. Elbaz A, Grigoletto F, Baldereschi M, Breteler MM, Manubens-Bertran JM, Lopez-Pousa S, Dartigues JF, Alperovitch A, Tzourio C, Rocca WA: Familial aggregation of Parkinson's disease: a population-based case-control study in Europe. EUROPARKINSON Study Group. Neurology 1999, 52(9):1876-1882

5. Payami H, Zareparsi S, James D, Nutt J: Familial aggregation of Parkinson disease: a comparative study of early-onset and late-onset disease. Arch Neurol 2002, 59(5):848-850.

6. Kitada T, Asakawa S, Hattori $N$, Matsumine $H$, Yamamura $Y$, Minoshima S, Yokochi M, Mizuno Y, Shimizu N: Mutations in the parkin gene cause autosomal recessive juvenile parkinsonism. Nature 1998, 392(6676):605-608.

7. Valente EM, Abou-Sleiman PM, Caputo V, Muqit MM, Harvey K, Gispert S, Ali Z, Del Turco D, Bentivoglio AR, Healy DG, et al.: Hereditary early-onset Parkinson's disease caused by mutations in PINK I. Science 2004, 304(5674): I I 58-I I 60.

8. Bonifati V, Rizzu P, van Baren MJ, Schaap O, Breedveld GJ, Krieger E, Dekker MC, Squitieri F, Ibanez P, Joosse M, et al:: Mutations in the DJ-I gene associated with autosomal recessive early-onset parkinsonism. Science 2003, 299(5604):256-259.

9. Ramirez A, Heimbach A, Grundemann J, Stiller B, Hampshire D, Cid LP, Goebel I, Mubaidin AF, Wriekat AL, Roeper J, et al.: Hereditary parkinsonism with dementia is caused by mutations in ATPI3A2, encoding a lysosomal type 5 P-type ATPase. Nat Genet 2006, 38(1 0): I |84-II91.

10. Lucking CB, Durr A, Bonifati V, Vaughan J, De Michele G, Gasser T, Harhangi BS, Meco G, Denefle P, Wood NW, et al.: Association between early-onset Parkinson's disease and mutations in the parkin gene. $N$ Engl J Med 2000, 342(2 I): I560-I567.

II. Yamamura Y, Sobue I, Ando K, lida M, Yanagi T: Paralysis agitans of early onset with marked diurnal fluctuation of symptoms. Neurology 1973, 23(3):239-244.

12. Ishikawa A, Tsuji S: Clinical analysis of 17 patients in 12 Japanese families with autosomal-recessive type juvenile parkinsonism. Neurology 1996, 47(I): I60-166.

13. Takahashi H, Ohama E, Suzuki S, Horikawa Y, Ishikawa A, Morita T, Tsuji S, Ikuta F: Familial juvenile parkinsonism: clinical and pathologic study in a family. Neurology I994, 44(3 Pt I):437-44I.

14. Mori H, Kondo T, Yokochi M, Matsumine H, Nakagawa-Hattori Y Miyake T, Suda K, Mizuno Y: Pathologic and biochemical studies of juvenile parkinsonism linked to chromosome 6q. Neurology 1998, 5 I (3):890-892.

15. Matsumine H, Saito M, Shimoda-Matsubayashi S, Tanaka H, Ishikawa A, Nakagawa-Hattori Y, Yokochi M, Kobayashi T, Igarashi S, Takano $H$, et al: Localization of a gene for an autosomal recessive form of juvenile Parkinsonism to chromosome 6q25.2-27 Am J Hum Genet 1997, 60(3):588-596.

16. Morett $E$, Bork P: A novel transactivation domain in parkin. Trends Biochem Sci 1999, 24(6):229-23I.

17. Abbas N, Lucking CB, Ricard S, Durr A, Bonifati V, De Michele G, Bouley S, Vaughan JR, Gasser T, Marconi R, et al.: A wide variety of mutations in the parkin gene are responsible for autosomal recessive parkinsonism in Europe. French Parkinson's Disease Genetics Study Group and the European Consortium on Genetic Susceptibility in Parkinson's Disease. Hum Mol Genet 1999, 8(4):567-574.

18. Hattori N, Kitada T, Matsumine H, Asakawa S, Yamamura Y, Yoshino H, Kobayashi T, Yokochi M, Wang M, Yoritaka A, et al.: Molecular genetic analysis of a novel Parkin gene in Japanese families with autosomal recessive juvenile parkinsonism: evidence for variable homozygous deletions in the Parkin gene in affected individuals. Ann Neurol 1998, 44(6):935-94I.

19. Hattori N, Matsumine H, Asakawa S, Kitada T, Yoshino H, Elibol B, Brookes AJ, Yamamura Y, Kobayashi T, Wang M, et al.: Point mutations (Thr240Arg and Gln3 I IStop) [correction of Thr240Arg and Ala3 I IStop] in the Parkin gene. Biochem Biophys Res Commun 1998, 249(3):754-758.

20. Leroy E, Anastasopoulos D, Konitsiotis S, Lavedan C, Polymeropoulos $\mathrm{MH}$ : Deletions in the Parkin gene and genetic heterogeneity in a Greek family with early onset Parkinson's disease. Hum Genet 1998, $103(4): 424-427$

21. Valente EM, Brancati F, Caputo V, Graham EA, Davis MB, Ferraris A Breteler MM, Gasser T, Bonifati V, Bentivoglio AR, et al.: PARK6 is a common cause of familial parkinsonism. Neurol Sci 2002, 23(Suppl 2):SII7-II8
22. West A, Periquet $M$, Lincoln S, Lucking CB, Nicholl D, Bonifati V, Rawal N, Gasser T, Lohmann E, Deleuze JF, et al.: Complex relationship between Parkin mutations and Parkinson disease. Am J Med Genet 2002, I I 4(5):584-59I.

23. Valente $E M$, Bentivoglio $A R$, Dixon $P H$, Ferraris $A$, lalongo $T$, Frontali M, Albanese A, Wood NW: Localization of a novel locus for autosomal recessive early-onset parkinsonism, PARK6, on human chromosome Ip35-p36. Am J Hum Genet 200I, 68(4):895-900.

24. Valente EM, Brancati F, Ferraris A, Graham EA, Davis MB, Breteler MM, Gasser T, Bonifati V, Bentivoglio AR, De Michele G, et al.: PARK6-linked parkinsonism occurs in several European families. Ann Neurol 2002, 5 I (I): |4-18.

25. Hatano $Y$, Li Y, Sato K, Asakawa S, Yamamura $Y$, Tomiyama $H$, Yoshino H, Asahina M, Kobayashi S, Hassin-Baer S, et al.: Novel PINKI mutations in early-onset parkinsonism. Ann Neurol 2004, 56(3):424-427

26. Rohe CF, Montagna P, Breedveld G, Cortelli P, Oostra BA, Bonifati V: Homozygous PINKI C-terminus mutation causing earlyonset parkinsonism. Ann Neurol 2004, 56(3):427-431.

27. Bonifati V, Rohe CF, Breedveld G], Fabrizio E, De Mari M, Tassorelli C, Tavella A, Marconi R, Nicholl DJ, Chien HF, et al.: Early-onset parkinsonism associated with PINKI mutations: frequency, genotypes, and phenotypes. Neurology 2005, 65(I):87-95

28. Zhang YH, Tang BS, Guo JF, Xia K, Xu B, Cai F, Deng HX, Yan XX, Chen T, Cao L, et al.: [Mutation analysis of PINKI gene in Chinese patients with autosomal recessive early-onset parkinsonism type 6]. Zhonghua Yi Xue Za Zhi 2005, 85(22):I538-I54I.

29. Ibanez P, Lesage S, Lohmann E, Thobois S, De Michele G, Borg M, Agid Y, Durr A, Brice A: Mutational analysis of the PINKI gene in early-onset parkinsonism in Europe and North Africa. Brain 2006, I 29(Pt 3):686-694.

30. Hiller A, Hagenah JM, Djarmati A, Hedrich K, Reetz K, SchneiderGold C, Kress W, Munchau A, Klein C: Phenotypic spectrum of PINKI-associated parkinsonism in 15 mutation carriers from I family. Mov Disord 2007, 22(I): |45-|47.

31. Valente EM, Salvi S, lalongo T, Marongiu R, Elia AE, Caputo V, Romito $L$, Albanese A, Dallapiccola B, Bentivoglio AR: PINKI mutations are associated with sporadic early-onset parkinsonism. Ann Neurol 2004, 56(3):336-34I.

32. Criscuolo C, Volpe G, De Rosa A, Varrone A, Marongiu R, Mancini P, Salvatore E, Dallapiccola B, Filla A, Valente EM, et al:: PINKI homozygous $\mathrm{W} 437 \mathrm{X}$ mutation in a patient with apparent dominant transmission of parkinsonism. Mov Disord 2006, 2 I(8): $1265-1267$

33. Sim CH, Lio DS, Mok SS, Masters CL, Hill AF, Culvenor JG, Cheng $\mathrm{HC}$ : C-terminal truncation and Parkinson's disease-associated mutations down-regulate the protein serine/threonine kinase activity of PTEN-induced kinase- I. Hum Mol Genet 2006, I 5(2 I):325 I-3262

34. Li Y, Tomiyama H, Sato K, Hatano Y, Yoshino H, Atsumi M, Kitaguchi $M$, Sasaki S, Kawaguchi S, Miyajima $H$, et al.: Clinicogenetic study of PINKI mutations in autosomal recessive early-onset parkinsonism. Neurology 2005, 64(I I): I955-1957.

35. Atsumi M, Li Y, Tomiyama H, Sato K, Hattori N: [A 62-year-old woman with early-onset Parkinson's disease associated with the PINKi gene deletion]. Rinsho Shinkeigaku 2006, 46(3): 199-202.

36. Healy DG, Abou-Sleiman PM, Gibson JM, Ross OA, Jain S, Gandhi S, Gosal D, Muqit MM, Wood NW, Lynch T: PINKI (PARK6) associated Parkinson disease in Ireland. Neurology 2004, 63(8): | 486-| 488 .

37. Klein C, Grunewald A, Hedrich K: Early-onset parkinsonism associated with PINK I mutations: frequency, genotypes, and phenotypes. Neurology 2006, 66(7): I I 29-I I 30. author reply I I 29II 30

38. Deng $H$, Le WD, Zhang $X$, Pan TH, Jankovic J: G309D and W437OPA PINKI mutations in Caucasian Parkinson's disease patients. Acta Neurol Scand 2005, I I I (6):35 I-352.

39. Silvestri L, Caputo V, Bellacchio E, Atorino L, Dallapiccola B, Valente EM, Casari G: Mitochondrial import and enzymatic activity of PINKI mutants associated to recessive parkinsonism. Hum Mol Genet 2005, I4(22):3477-3492.

40. Rawal N, Periquet M, Lohmann E, Lucking CB, Teive HA, Ambrosio G, Raskin S, Lincoln S, Hattori N, Guimaraes J, et al.: New parkin mutations and atypical phenotypes in families with auto- 
somal recessive parkinsonism. Neurology 2003, 60(8): $|378-| 38 \mid$.

41. Lohmann E, Periquet M, Bonifati V, Wood NW, De Michele G, Bonnet AM, Fraix V, Broussolle E, Horstink MW, Vidailhet M, et al:: How much phenotypic variation can be attributed to parkin genotype? Ann Neurol 2003, 54(2): I76-185.

42. Bonifati V, De Michele G, Lucking CB, Durr A, Fabrizio E, Ambrosio G, Vanacore N, De Mari M, Marconi R, Capus L, et al.: The parkin gene and its phenotype. Italian PD Genetics Study Group, French PD Genetics Study Group and the European Consortium on Genetic Susceptibility in Parkinson's Disease. Neurol Sci 200I, 22(I):5I-52

43. Denison SR, Callahan G, Becker NA, Phillips LA, Smith DI: Characterization of FRA6E and its potential role in autosomal recessive juvenile parkinsonism and ovarian cancer. Genes Chromosomes Cancer 2003, 38(I):40-52.

44. Quinn N, Critchley P, Marsden CD: Young onset Parkinson's disease. Mov Disord 1987, 2(2):73-91.

45. Schlitter AM, Kurz M, Larsen JP, Woitalla D, Mueller T, Epplen JT, Dekomien G: Exclusion of PINKI as candidate gene for the late-onset form of Parkinson's disease in two European populations. J Negat Results Biomed 2005, 4:10.

46. Groen JL, Kawarai T, Toulina A, Rivoiro C, Salehi-Rad S, Sato C, Morgan A, Liang Y, Postuma RB, St George-Hyslop P, et al:: Genetic association study of PINKI coding polymorphisms in Parkinson's disease. Neurosci Lett 2004, 372(3):226-229.

47. Funayama M, Li Y, Tsoi TH, Lam CW, Ohi T, Yazawa S, Uyama E, Djaldetti R, Melamed E, Yoshino H, et al.: Familial Parkinsonism with digenic parkin and PINKI mutations. Mov Disord 2008, 23(10): I 46I-I 465.

48. Periquet M, Lucking C, Vaughan J, Bonifati V, Durr A, De Michele G, Horstink M, Farrer M, Illarioshkin SN, Pollak P, et al:: Origin of the mutations in the parkin gene in Europe: exon rearrangements are independent recurrent events, whereas point mutations may result from Founder effects. Am J Hum Genet 200I, 68(3):617-626.

49. Hedrich K, Eskelson C, Wilmot B, Marder K, Harris J, Garrels J, MeijaSantana H, Vieregge P, Jacobs H, Bressman SB, et al.: Distribution, type, and origin of Parkin mutations: review and case studies. Mov Disord 2004, I 9( I 0): I | 46-I I 57.

50. Clarimon J, Johnson J, Dogu O, Horta W, Khan N, Lees AJ, Hardy J, Singleton A: Defining the ends of Parkin exon 4 deletions in two different families with Parkinson's disease. Am J Med Genet B Neuropsychiatr Genet 2005, I33B(I): 120-123.

5I. Denison SR, Wang F, Becker NA, Schule B, Kock N, Phillips LA, Klein C, Smith DI: Alterations in the common fragile site gene Parkin in ovarian and other cancers. Oncogene 2003, 22(5 I):8370-8378.

52. Chaudhary S, Behari M, Dihana M, Swaminath PV, Govindappa ST, Jayaram S, Goyal V, Maitra A, Muthane UB, Juyal RC, et al:: Parkin mutations in familial and sporadic Parkinson's disease among Indians. Parkinsonism \& related disorders 2006, I 2(4):239-245.

53. Biswas A, Gupta A, Naiya T, Das G, Neogi R, Datta S, Mukherjee S, Das SK, Ray K, Ray J: Molecular pathogenesis of Parkinson's disease: identification of mutations in the Parkin gene in Indian patients. Parkinsonism \& related disorders 2006, 12(7):420-426.

54. Madegowda RH, Kishore A, Anand A: Mutational screening of the parkin gene among South Indians with early onset Parkinson's disease. Journal of neurology, neurosurgery, and psychiatry 2005, 76(II): I588-1590.

55. Lucking $C B$, Chesneau $V$, Lohmann E, Verpillat $P$, Dulac $C$, Bonnet AM, Gasparini F, Agid Y, Durr A, Brice A: Coding polymorphisms in the parkin gene and susceptibility to Parkinson disease. Arch Neurol 2003, 60(9): I253-I256.

56. Biswas A, Maulik M, Das SK, Ray K, Ray J: Parkin polymorphisms: risk for Parkinson's disease in Indian population. Clinical genetics 2007, 72(5):484-486.

57. Wang F, Feng X, Ma J, Zou H, Chan P: A common A340T variant in PINKI gene associated with late-onset Parkinson's disease in Chinese. Neurosci Lett 2006, 410(2): 12I-I 25.

58. Toft M, Myhre R, Pielsticker L, White LR, Aasly JO, Farrer MJ: PINK I mutation heterozygosity and the risk of Parkinson's disease. Journal of neurology, neurosurgery, and psychiatry 2007, 78(I):82-84.

59. Fung $H C$, Chen $C M$, Hardy J, Singleton $A B$, Lee-Chen G], Wu YR. Analysis of the PINKI gene in a cohort of patients with spo- radic early-onset parkinsonism in Taiwan. Neurosci Lett 2006, 394(I):33-36.

\section{Pre-publication history}

The pre-publication history for this paper can be accessed here:

http://www.biomedcentral.com/1471-2377/8/47/prepub
Publish with Biomed Central and every scientist can read your work free of charge

"BioMed Central will be the most significant development for disseminating the results of biomedical research in our lifetime. "

Sir Paul Nurse, Cancer Research UK

Your research papers will be:

- available free of charge to the entire biomedical community

- peer reviewed and published immediately upon acceptance

- cited in PubMed and archived on PubMed Central

- yours - you keep the copyright

Submit your manuscript here:

http://www.biomedcentral.com/info/publishing_adv.asp 